\title{
血精液症の MRI
}

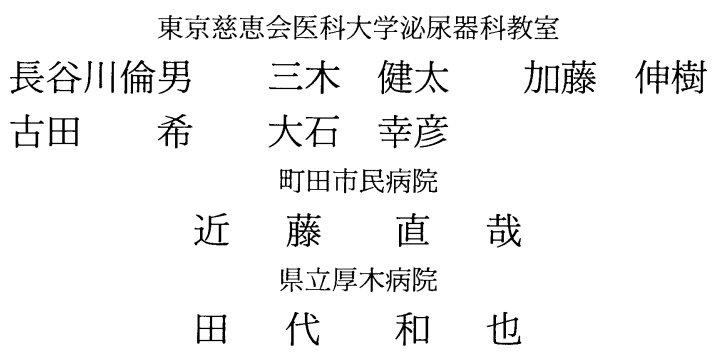

MAGNETIC RESONANCE IMAGES OF HEMATOSPERMIA

Norio Hasegawa, Kenta Miki, Nobuki Kato, Nozomu Furuta and Yukihiko Ohishi

Department of Urology, Jikei University, School of Medicine

Naoya Kondo

Machida Municipal Hospital

Kazuya Tashiro

Department of Urology, Kanagawa Prefectural Atsugi Hospital

(Background) We performed MRI (magnetic resonance imaging) in the pelvic region of 70 cases with hematospermia and conducted a study on the abnormal MRI findings to which hematospermia could be attributed.

(Methods) We conducted a study on the morphological anomality and change in the signal intensity in the prostate gland and of the seminal vesicle as well as on the presence or absence of dilation in the plexus venous surrounding the deferent duct or the prostate gland out of the abnormal MRI findings. As for the seminal vesicle, the patients whose seminal vesicle was seen in higher intensity than the prostate gland in T1 weighted images were diagnosed as having hemorrhagic focus and the patients whose seminal vesicle was seen in low intensity both in T1 and T2 weighted images were diagnosed as having fibrosis caused by chronic inflammation.

(Results) Abnormal MRI findings were seen in 40 out of the 70 cases (57\%). Anomality in the prostate gland was indicated in $6(9 \%)$ cases. Abnormality in the seminal vesicle was indicated in 30 cases $(43 \%)$ including hemorrhage of seminal vesicle in 25 cases, chronic inflammation in five cases and cyst of seminal vesicle in one case.

(Conclusion) In conducting an examination of the patients with hematospermia, MRI is the nonivasive and reproducible method and it is possible to identify the hemorrhagic region. Therefore, MRI is thought to be useful to identify the causal organs of hematospermia.

Key words: hematospermia, MRI

要旨：(目的）血精液を主訴として来院した70症例に対し，骨盤部 MRI (magnetic resonance imaging) 検查を施行し，血精液症の原因と思われる異常所見について検討を行った。

(方法) MRI における異常所見として, 前立腺と精囊の形態異常および信号強度の変化, さらに精管, 前立腺周囲静脈叢の拡張の有無を検討した. 精囊については, 精囊内容が T1強調画像で前立腺よりも高 信号を示した場合を出血巣とし，T1，T2ともに低信号を示した場合を慢性炎症による線維化とした。

(結果) 全70症例中, MRI で異常所見を認めた症例は40例（57\%）であった。このうち前立腺に異常 を認めた症例は 6 例 $(9 \%$ ）で，前立腺肥大が 5 例，前立腺癌が疑われた症例が 1 例であった，精聂に 
異常を認めた症例は30例（43\%）で, 精囊出血が25例, 慢性炎症が 5 例, 精囊囊胞が 1 例であった。

(結論）血精液症における MRI は，今回の検討では $57 \%$ に異常所見が発見され，精管造影より非侵襲 的で，超音波検査にくらべ再現性があり，また CTより情報量が多いことより血精液症の原因臓器の検 索に有用であると思われた。

キーワード：血精液症, MRI

\section{緒 言}

血精液症は前立腺や精囊, 精管の器質的変化や機能 的異常により生じるとされるが原因が判然とせず，患 者への説明に苦慮することが多い. 原因の検索に膀胱 鏡や骨盤部 CT, 超音波診断, 精管造影などが行われる が，明らかな異常所見を呈することは少なく，とくに 微少出血や炎症所見の確認は困難である．現在まで血 精液症に対し, magnetic resonance imaging（以下 MRI)による評価の報告は少ない(1)10111)。今回，血精液 を主訴として来院した症例に対し，骨盤部 MRI 検査 を施行し，異常所見の発生頻度とその部位ならびに本 法の有用性を評価した。

\section{対象および方法}

1993年10月より1997年 8 月までの 4 年間に慈恵医 大，町田市民病院および県立厚木病院で血精液症を主 訴に受診した70症例（67名）を対象とした。年齢は 21〜 74 (平均 $47 \pm 2$ ) 歳, 初診時に尿潜血を認めたもの は 6 例で， 1 例に膿尿を認めた。

MRI は67名全例に施行し,さらに血精液が消失した 後に 2 例, 血精液が継続した 1 例に MRI を再施行し た。

また全例に直腸診を行い，硬結を触知するなどの異 常を認めた 3 例は CT も施行した. MRI で異常を認め た 5 例（精囊出血 4 例, 前立腺癌の疑い 1 例）に経直 腸超音波検査を施行し, MRI で異常が見られず血精液 が続いた 6 例に膀胼鏡を施行した。

MRI 診断装置はフィリップスメディカルシステム ズ社 GYROSCAN T5（0.5テスラ）および東芝社 VISART(1.5テスラ)を使用した。撮像は SE 法で T1 強調画像 (GYROSCAN : TR 620msec/TE $15 \mathrm{msec}$, マトリックス $256 \times 256$, スライス厚 $6 \mathrm{~mm}$, FOV 250, VISART : TR440 470msec/TE $17 \mathrm{msec，マトリッ}$ クス $208 \times 208$ ，スライス厚 $4 \mathrm{~mm}$, FOV 230 240mm) を撮像後, 高速 SE 法で T2強調画像 (GYROSCAN : TR 4,200msec/TE $120 \mathrm{msec}$, マトリックス $256 \times 256$, スライス厚 $6 \mathrm{~mm}$, FOV 250, VISART：TR $2,500 \sim 3,200 \mathrm{msec} / \mathrm{TE} 107 \mathrm{msec}$, マトリックス224× 224 , スライス厚 $4 \mathrm{~mm}, \mathrm{FOV} 230 \sim 240 \mathrm{~mm}$ ）を横断像
で表面コイルを使用した。

血精液症出現から MRI 施行までの期間は可能な限 り短期間になるように考慮した。また MRI 施行前は 原則として 4 日以上の禁欲とし, MRI 施行後の血精液 症の有無を問診で確認した。

MRIにおける異常所見の判定方法は,

(1) 前立腺と精囊の形態異常および信号強度の変化

(2) 精管の拡張

(3) 前立腺周囲静脈叢の拡張の有無 の 3 項目を検討した.

精囊については Secaf ${ }^{2)}$ ら報告にもとづき, 精囊の 幅が $2 \mathrm{~cm}$ 以上を異常拡張とし, 精囊内容の一部が $\mathrm{T} 1$ 強調画像で前立腺よりも高信号を示した場合を出血巣 またはムチン様液貯留, 精囊の一部が萎縮し, T1, T2 ともに低信号を示した場合を慢性炎症による線維化と 診断した.

いずれも加齢による変化（70歳以下の精囊は全体的 に脂肪と同またはやや高信号，70歳をこえると脂肪と 同または低信号を呈する）を考慮した。

血精液症の治療は，全例に初診時より止血剂を投与 し，炎症所見のみられた症例には抗生剤も投与した。

\section{結 果}

MRI で全70症例中40例 (57\%) に異常所見を認めた。 前立腺に異常を認めた症例は 6 例 $(9 \%)$ で前立腺肥大 5 例, 残りの 1 例は peripheral zone の一部が T2低信 号を示し，前立腺癌が疑われた．精囊に異常を認めた 症例は30例 (43\%) で，精囊出血 24 例，慢性炎症 4 例， 精囊出血および炎症の合併が 1 例, 精囊囊胞が 1 例で あった。精囊の異常30例中19例は左側，右側 9 例，両 側 2 例であった。精囊出血を認めた症例において MRI で陰囊内容を確認したが，出血や水腫などの異常を認 めなかった。

前立腺周囲静脈叢の拡張 3 例, 精管膨大部の拡張は 1 例に認めた。

前立腺癌を疑った症例は，経直腸超音波検査で異常 は認めず，血清前立腺特異抗原が $6.8 \mathrm{ng} / \mathrm{ml}$ (正常值 $<$ 3.0) とやや高值であったため前立腺針生検を行った が, 組織学的に悪性細胞を認めなかった. 生検後 6 力 


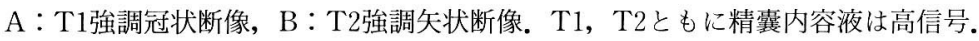
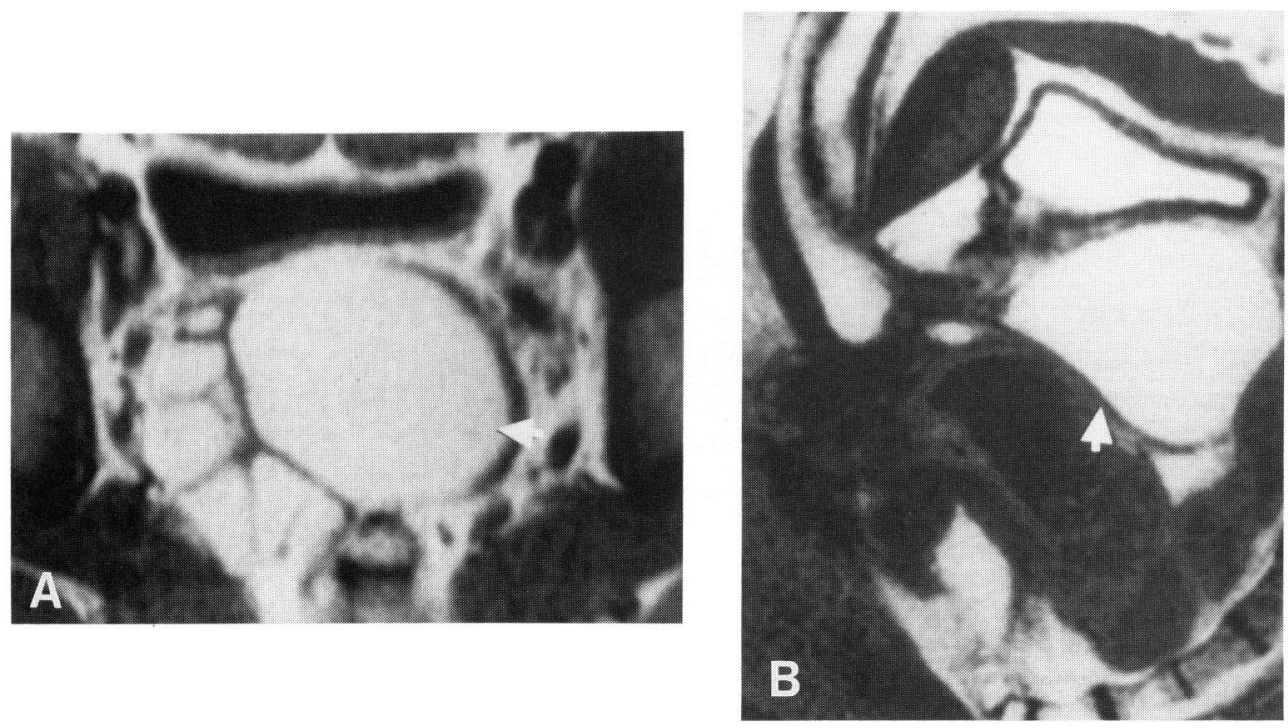

月の時点で血精液を認めていない. 精囊囊胞は, 精囊 が多房性に腫大し，T1，T2ともに高信号を示した(図 1). 囊胞を超音波ガイド下に穿刺したところ，ムチン 状の内容液が得られた。この症例はほほ 1 年おきに囊 胞穿刺を必要とし，血精液症も続いている.

直腸診で前立腺に異常を認めた 3 例に骨盤部 CTを 施行し，うち 2 例で前立腺結石を認めたが，MRIでは 結石の診断はできなかった. MRIで精囊出血のみを認 めた 4 例に経直腸超音波検查を施行したが, 精囊の拡 張などの異常を認めなかった。

血精液症の転㴆は, 前立腺針生検を施行した 1 例と 精囊囊胞の 1 例をのぞき, 外科的治療は必要とせず経 過観察とした. MRIで異常がなかった 30 例中 15 例は MRI 施行直後の問診で血精液の消失を確認したが， 6 例はMRI 直後も血精液が認められた。この 6 例に膀 胱鏡を施行したが, 尿道, 膀胱内に異常を認めなかっ た.MRIで異常を認めた40例中 32 例は MRI 直後も血 精液を認め, 精囊に異常所見を認めた全例に血精液を 確認した. 精囊出血を認め, 血精液が消失した後に MRI を再施行した 2 例ともに精囊の出血の所見は消 失していた。精囊出血を認め, 血精液が消失しなかっ た 1 例にMRI を再施行したが, 出血の所見は依然認 められた。

\section{考 察}

血精液症は臨床的によく見られる疾患であるが，し
ばしば原因がはっきりしない.血精液症の原因臟器は, 精囊と前立腺, 精管が主なものとされ ${ }^{3 / 4)}$, 各臓器にお ける器質的変化や機能的異常, 特に炎症やアレルギー によるものが多いとされる5.

原因の検索に膀胱鏡や CT, 超音波検査, 精管造影な どが行われ, 尿道の異常や前立腺の腫大, 精囊の拡張 などの形態異常が報告されている $\left.{ }^{6)} 8\right)$ が, 従来の画像 診断法では炎症や微少出血の所見を認めることは少な い. MRI は蔵器の炎症や出血の診断が可能であること から, 血精液症の原因㵴器を特定するために有用な画 像診断法と思われる.

MRIにおける成人の正常な精囊の所見は, Secaf ら ${ }^{2)}$ によると精囊の長さは $3 \sim 6 \mathrm{~cm}$ ，幅は8～20 mm, T1 で前立腺にくらべ同またはやや低信号, T2で脂肪組織 にくらべ高信号である。また約10\%の症例で大きさに 左右差がみられるが, MRI の信号強度に左右差は無い とされる. 急性, 亜急性の炎症で精囊は通常腫大し, T1，T2ともに正常または低信号となる.血精液をとも なう場合は撮像時期により多少変化するが, T1高信 号, T2高または低信号をしめすことが多い(図 2 ). 慢 性の炎症では T1, T2 ともに両側あるいは片側性に萎 縮し，低信号となる（図 3 )。

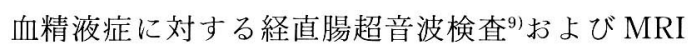
の諸家の報告 ${ }^{10) 11}$ ) と自験例を比較した（表 1 )。いずれ の検査でも前立腺の異常は $10 \%$ 前後で, 精囊の異常を 
図 2 左精囊出血 (矢印)

$\mathrm{A} ： \mathrm{~T} 1$ 強調横断像, $\mathrm{B}$ ：T2強調横断像. 左精囊は T1強調像で軽度の高信号を示し, 血 液の貯留が示唆される。
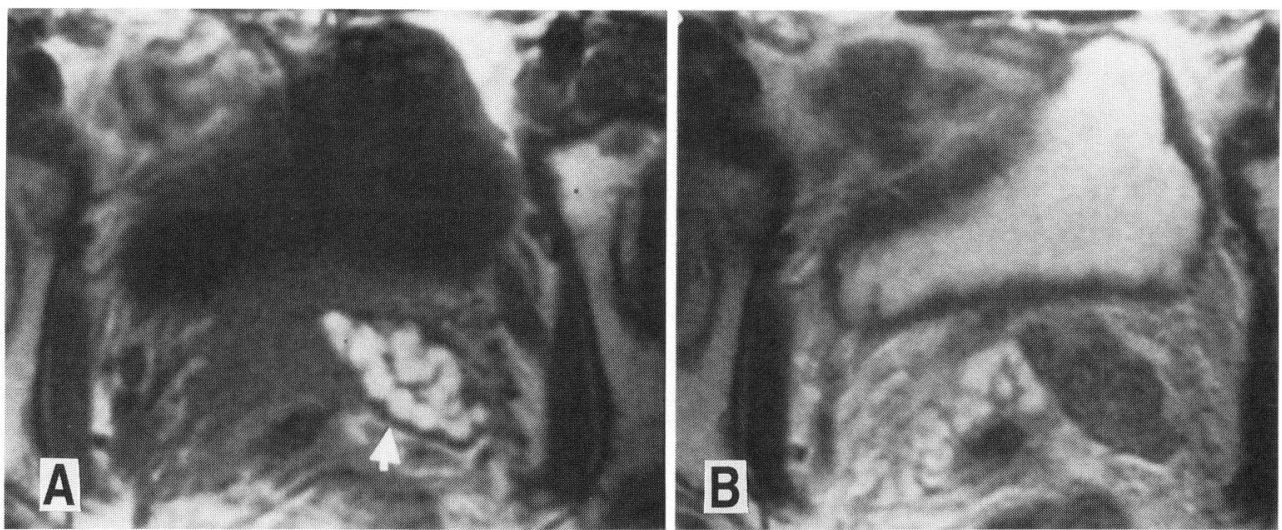

図 3 左精囊の慢性炎症（矢印）

A：T1強調横断像，B：T2強調横断像，左精囊は T2で低信号を示し，片側性に萎縮。
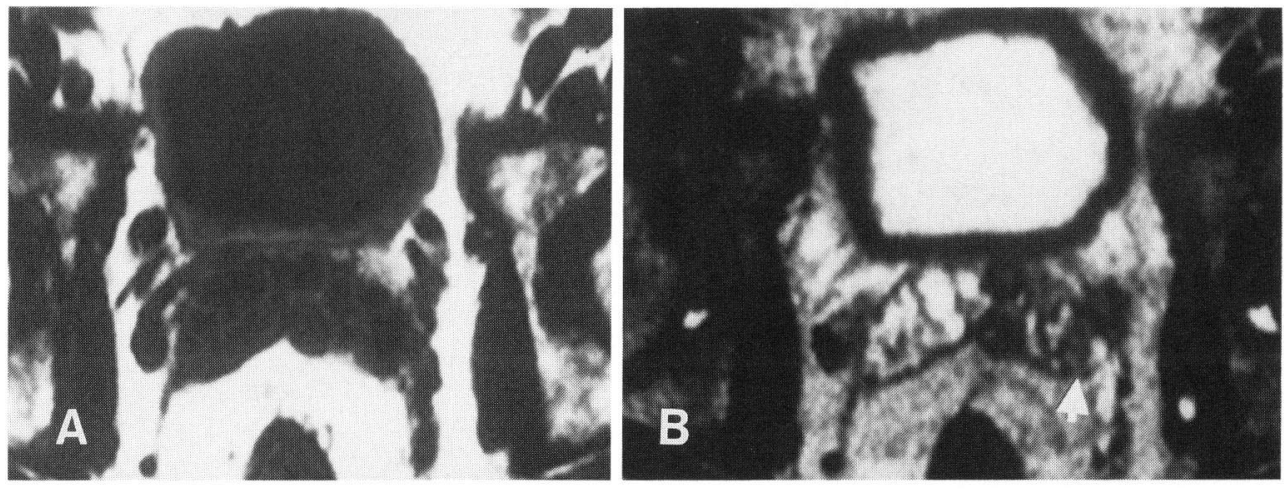

表 1 血精液症にたいする経直腸超音波検查(TRUS) と MRI の異常所見の比較

\begin{tabular}{|c|c|c|c|c|c|}
\hline & & 前立腺 & & 霅 & 精管 \\
\hline & 症例 & & 形態異常 & 信号強度の異常 & 形態異常 \\
\hline $\begin{array}{l}\text { TRUS } \\
\text { (Worischeeck } 5^{9)} \text { ) }\end{array}$ & 26例 & 3例 (12\%) & 16例 (62\%) & & 4例 $(15 \%)$ \\
\hline $\begin{array}{l}\text { MRI } \\
\text { (Maeda } ら^{11)} \text { ) }\end{array}$ & 15例 & 1例 $(6 \%)$ & 13例 (87\%) & 11例 (73\%) & 3 例 $(20 \%)$ \\
\hline $\begin{array}{l}\text { MRI } \\
\text { (渡辺ら } \\
\left.{ }^{101}\right)\end{array}$ & 39例 & 7 例 $(18 \%)$ & 4例 (10\%) & 9例 $(23 \%)$ & \\
\hline $\begin{array}{l}\text { MRI } \\
\text { (自験例) }\end{array}$ & 70 例 & 7 例 (10\%) & 7例 (10\%) & 31 例 (44\%) & 1例(1\%) \\
\hline
\end{tabular}

認めたものが多く，さらに精管の形態異常も報告され ている. MRI に扔ける Maeda ${ }^{11} ら の$ 報告では, 精囊の 形態異常が13/15 (87\%) と多い. Maeda らは健常者の
精囊管の検討を行い， $0.5 \mathrm{~cm}$ 以上を拡張所見としてい る.著者らは禁欲による精液の貯溜を考え，さらに健 常者の $10 \%$ は左右非対称であることより，明らかに片 
側性に腫大している精霊や, 精囊の幅が $2 \mathrm{~cm}$ 以上を異 常としたため, 今回の検討では精囊の形態異常を呈し た症例は 5 例 (1\%) と少なかった. 信号強度の変化に ついては, 出血あるいは炎症の生じた時期により所見 が変化するため, とくに症状出現から MRI までの期 間が 1 力月以上長くなった場合, 原因部位の判定は困 難になる.さらに, MRI 検査時には血精液が消失して いる可能性もあり, より早期の MRI 施行が望まれる. T1強調画像で高信号を出血巣の所見とした場合, 今回 の検討では精囊出血が25例（36\%）と一番多く認めら れた。

血精液症における MRI は, 今回の検討でも異常所 見の発見頻度が高い $(47 \%)$ こ, 膀胱鏡や精管造影 に比較し非侵襲的であること, 超音波検査にくらべ再 現性が高いこと, また CT より情報量が多く, 造影 CT よりも保険点数は安価であることより, 血精液症の原 因部位の検索に有用であると思われる.

Mulhall らは血精液症について, 悪性疾患に基づく ものは少なく特別な治療を要することはまれであるた め, 患者に安心感を与えればよいと述べている ${ }^{12)}$. MRI で血精液症の原因を同定することは困難である が，患者に出血部位を提示できるという点で意義のあ る検査と言える。

\section{文献}

1）廣瀬鉄次郎, 浜走倫人, 岩崎尚弥：血精液症におけ る精囊の MRI. 泌尿外, 4, 473-476，1991.

2) Secaf, E., Nuruddin, R. N., Hricak, H., McClure, R.D. and Demas, B. : MR Imaging of the Semi- nal Vesicles. Am. J. Roentgenol., 156, 989—994, 1991.

3) Huggins, C. and McDonald, D.F.: Chronic hematospermia ; its origin and treatment with estrogen. J. Clin. Endoclinol., 5, 226-231, 1945.

4）川村健二, 伊藤晴夫, 島崎 淳: 血精液症. 西日泌 尿, 44, 1173-1176, 1982.

5）矢田文平：On the study of hemospermia. 泌尿 紀要， 9，175-206，1963.

6）宋 成浩, 川上達夫, 頴川 晋, 内田豊昭, 小柴 健：超音波法による前立腺と精襄の囊胞性の診 断. 泌尿紀要, 41, 33-37, 1995.

7) Weintraub, M.P., De Mouy, E. and Hellstrom, W.J.G.: Newer modalities in the diagnosis and treatment of ejaculatory duct obstraction. J. Urol., 150, 1150-1154, 1995.

8）石神襄次：血精液症. 精霊, 初版, p179-187, 株 式会社ミクス, 東京, 1991.

9) Worischeck, J.H. and Parra, R.O.: Chronic Hematospermia: Assessment by transrectal ultrasound. Urology, 43, 515-520, 1994.

10) 渡辺 聡, 南壮太朗, 徳永正俊, 恩田一, 河村信 夫：血精液患者の MRI 所見について. 泌尿外, 9, 487-491, 1996.

11) Maeda, H., Toyooka, N., Kinukawa, T., Hattori, R. and Furukawa, T.: Magnetic resonance images of hematospermia. Urology, 41 , 499-504, 1993.

12) Mulhall, J.P. and Albertsen, P.C.: Hemospermia : Diagnosis and management. Urology, 46, 463-467, 1995.

（1998年2月10日受付，8月6日受理） 